\title{
MENINGKATKAN HASIL BELAJAR KIMIA MELALUI MODEL COOPERATIVE LEARNING DENGAN TIPE JIGSAW DI KELAS XI IPA SMA NEGERI 1 BATAM
}

\section{IMPROVING CHEMISTRY LEARNING OUTCOMES THROUGH COOPERATIVE LEARNING MODELS WITH JIGSA W IN XI IPA SMA 1 BATAM}

\author{
Meriati Purba \\ SMA Negeri 1 Batam \\ Jl. R. Soeprapto, Sei Harapan, Sekupang, Batam 29432 \\ *e-mail korespondensi: meripurba17@gmail.com
}

\begin{abstract}
Abstrak
Aktivitas belajar dapat ditingkatkan melalui model Jigsaw Learning. Penelitian ini adalah penelitian tindakan kelas (class action research) sebagai subjek penelitian adalah siswa kelas XI IPA SMA Negeri 1 Batam Tahun Ajaran 2018/2019 yang berjumlah 36 orang. Metode penelitian dengan pengumpulan data dan menggunakan tes tertulis, serta lembar observasi. Langkah-langkah pelaksanaannya terdiri dari tiga siklus dan setiap siklus terdiri dari tiga kali pertemuan. Dari setiap siklus penelitian diperoleh data dari tes setelah proses (post tes), angket yang diisi siswa dan lembaran observasi siswa. Data yang diperoleh dianalisis dan dijadikan sebagai bahan acuan untuk perencanaan dan pelaksanaan siklus berikutnya. Hasil Penelitian Tindakan Kelas yang penulis lakukan manunjukkan adanya peningkatan nilai rata-rata kelas hasil belajar siswa, yaitu dari siklus I sebesar 73,4, siklus II sebesar 79,3, dan siklus III sebesar 81,0. Aktivitas siswa selama proses pembelajaran juga menunjukkan peningkatan ketuntasan hasil belajar perkelas yaitu siklus I $50 \%$, siklus II $70 \%$, dan siklus III $90 \%$. Selain itu juga terlihat motivasi yang tinggi dari siswa untuk belajar. Pengamatan penulis di kelas selama penelitian ini menunjukkan perubahan sikap, dan tingkah laku siswa, yang pada awalnya pasif dan kurang kreatif dalam pembelajaran berubah menjadi lebih aktif dan kreatif. Perubahan ini karena siswa langsung dilibatkan dalam proses pembelajaran. Dengan menggunakan model Jigsaw learning dalam pembelajaran kimia, guru sebagai motivator dan fasilitator mampu menciptakan kondisi pembelajaran yang aktif dan inovatif.
\end{abstract}

Kata kunci: hasil belajar, model jigsaw, proses pembelajaran

\begin{abstract}
Learning activity can be increased thorough the jigsaw model learning. This study is classroom action research and the subject of research are students of XI IPA high school class 2018/2019 there are 36 students. The research method with test and observation. The step of its implementation consist of three cycles and each cycle consist of three times of learning. Each cycle is obtained the data of post test, questionnaire, and observation sheets. Data aquired analyzed and acquired as material for planning and implementasion of the next cycle. Results of clasroom action research represent increase the average class of learning students, from the first cycle is 73 , the second cycle is 79,3 and the third cycle is 81,0 . Student activity during the division process also showed an increase in the results of learning each classes. Fist cycle is 50\%, second cycle is $70 \%$ and third cycle is $90 \%$. In addition result of this research represent to student's high motivation. Result of observation at class during research showing attitude changes and behavior of student to become more active and creative.
\end{abstract}

Keywords: learning achievement, jigsaw model, learning process 


\section{PENDAHULUAN}

Dengan adanya perubahan kurikulum pendidikan dari KTSP 2006 menjadi kurikulum 2013, dimana adanya perubahan proses pembelajaran yang bukan hanya berpusat pada guru namun diharapkan berorientasi pada siswa yang lebih aktif. Sesuai perkembangan masyarakyat dari waktu kewaktu yang selalu berkembang, maka pendidikan para siswa haruslah mengikuti perkembangan zaman.

Guru dalam melaksanakan tugasnya harus memahami peran, fungsi dan kegunaan mata pelajaran yang diajarnya agar pembelajaran yang dikelasnya lebih efektip. Selain pemahaman akan hal-hal tersebut keefektipan itu juga ditentukan oleh kemampuan guru untuk merubah model pengajaran menjadi model pembelajaran sesuai yang diharapkan oleh Permen No 22 tahun 2016 tentang standar proses.

Penggunaan model-model pembelajaran juga merupakan hal yang sangat penting dalam upaya memajukan suatu bidang tertentu. Model sangat berkaitan dengan teori. Model merupakan suatu analog konseptual yang digunakan untuk menyarankan bagaimana meneruskan penelitian empiris sebaiknya tentang suatu masalah.

Dari semua uraian di atas dapat diketahui hal-hal yang perlu dalam upaya meningkatkan aktivitas dan prestasi belajar siswa seperti penguasaan metode-metode ajar; penguasaan model-model pembelajaran; penguasaan teoriteori belajar; penguasaan teknik-teknik tertentu; penguasaan peran, fungsi serta kegunaan mata pelajaran. Apabila betul-betul guru menguasai dan mengerti tentang hal-hal tersebut dapat diyakini bahwa prestasi belajar peserta didik pada mata pelajaran Kimia tidak akan rendah. Namun kenyataannya keaktifan belajar dan prestasi belajar siswa kelas XI IPA di semester ganjil tahun ajaran 2018/2019 baru mencapai nilai cukup dengan rata-rata 65 .

Melihat kesenjangan nilai KKM yang diharapkan masih jauh dari hasil yang diperoleh para siswa dikelas. Dalam Upaya memperbaiki mutu pendidikan hususnya pelajaran kimia sangat perlu dilakukan strategi perbaikan pembelajaran baik dengan penggunaan modelmodel pembelajaran (Zaini, 2008). Salah satunya dengan menggunakan model pembelajaran jigsaw learning.

Melihat adanya kesenjangan antara harapan dengan kenyataan yang ada di lapangan seperti yang sudah dipaparkan, maka terbentuklah rumusan penelitian ini yakni 1)
Apakah model pembelajaran Kooperatif Jigsaw dapat meningkatkan aktivitas belajar siswa kelas XI IPA SMA N 1 Batam? 2) Apakah model pembelajaran Kooperatif Jigsaw dapat meningkatkan prestasi belajar siswa kelas XI IPA SMA N 1 Batam?

Model pembelajaran Kooperatif Jigsaw merupakan salah satu dari banyak cara yang bisa dilakukan guru dalam upaya meningkatkan mutu pembelajaran (Sugianto, 2010). Model ini mempunyai keaktifan siswa dalam belajar dengan cara memberikan kesempatan bagi siswa untuk siap tampil dihadapan teman-temannya agar mampu tampil dihadapan orang banyak bukanlah hal yang gampang. Hal itu memerlukan persiapan yang matang, guru memberi kesempatan agar siswa menyiapkan sebaik-baiknya apa yang akan ditampilkan dihadapan siswa-siswa yang lain.

Contoh sebab akibat tersebut adalah, apabila siswa giat mengikuti pelajaran, akibatnya adalah mampu memberi tampilan yang diharapkan. Siswa akan menjadi aktif akibat diberikan giliran untuk berbicara di depan teman-temannya, yang sudah pasti akan menimbulkan tuntutan-tuntutan kemampuan yang tinggi baik dalam penampilan maupun keilmuan. Tanpa keilmuan yang mencukupi tidak akan mungkin tampilannya akan memuaskan, dalam hal ini siswa tidak bisa sembarangan saja, mereka harus betul-betul mampu menyimpulkan terlebih dahulu apa yang mereka akan bicarakan. Tuntunan langkahlangkah, motivasi, interpretasi yang inovatif dipihak guru akan menentukan keberhasilan pelaksanaan model ini.

Dari uraian singkat ini jelas bahwa model pembelajaran Kooperatif Jigsaw menuntut kemampuan siswa untuk giat mempelajari apa yang disampaikan guru, mampu menampilkan dirinya di depan siswa-siswa yang lain. Dipihak lain, untuk dapat menyelesaikan tuntutan tersebut, inovasi yang dilakukan guru akan sangat menentukan. Inovasi tersebut berupa tuntunan-tuntunan, motivasi-motivasi, interpre-tasi serta kemampuan implementasi yang tinggi. Cara inilah yang dapat digunakan sebagai dasar pemecahan masalah yang ada.

Adapun tujuan penelitian kali ini yaitu untuk: 1) mengetahui apakah model Jigsaw Learning dapat meningkatkan aktivitas belajar dan meningkatkan pemahaman konsep Kimia di SMA Negeri 1 Batam; dan 2) mengetahui apakah model Jigsaw Learning dapat meningkatkan hasil belajar siswa pada mata 
pelajaran kimia. Sehingga hipotesis penelitian dirumuskan sebagai berikut "terdapatnya peningkatan hasil belajar dan pemahaman konsep kimia di kelas X1 IPA, melalui model pembelajaran jigsaw”.

Penelitian Tindakan Kelas ini diharapkan dapat memberikan manfaat bagi berbagai pihak, diantaranya pada pihak siswa, yakni: 1) Siswa termotivasi dan dapat mengubah sikap atau perilaku siswa dalam proses pembelajaran; 2) aktivitas siswa semakin meningkat dalam belajar; 3) meningkatkan pemahaman konsep Kimia siswa sehingga otomatis dapat meningkatkan nilai rata-rata kimia. Manfaat bagi pihak guru, yaitu: 1) Sebagai pedoman pemecahan masalah pembelajaran yang ditemukan guru di kelas; 2) menambah wawasan guru dalam melaksanakan proses pembelajaran diantaranya dengan menggunakan model Jigsaw learning; 3) meningkatakan kemauan dan kemampuan guru untuk dapat menganalisa proses pembelajaran dan mengadakan perbaikan dalam rangka meningkatakan mutu PBM yang dikelolanya. Dan manfaat bagi pihak sekolah yakni: 1) Mutu dan kualitas sekolah dapat ditingkatkan melalui peningkatan prestasi belajar siswa; dan 2) Sebagai acuan bagi sekolah dalam memberikan kesempatan, fasilitas dan dukung bagi guru yang menemukan berbagai strategi atau model pembelajaran yang berhasilguna dan berdaya guna.

\section{METODE PENELITIAN}

Penelitian dilakukan di SMA Negeri 1 Batam Tahun Pelajaran 2018/2019. Subyek penelitian adalah siswa kelas XI IPA 1 sebanayak 36 orang yang memiliki kemampuan yang sedang.

Adapun persiapan penelitian yaitu diawali dengan membuat silabus, RPP atau skenario pembelajaran. Menjelaskan KD dan indikaor-indikator kepada siswa sebagai subyek penelitian, membuat lembar observasi peserta didik, guru teman sejawat atau observer serta angket dan alat evaluasi. Serta yang terakhir menjelaskan tentang model jigsaw learning.

Prosedur penelitian ini yaitu perencanan, pelaksanaan, pengamatan (observasi) dan refleksi. Dan data yang dikumpulkan pada tiap pertemuan meliputi data aktivitas siswa dalam kegiatan diskusi kelompok belajar, kelompok Jigsaw, dan tes hasil belajar serta angket siswa. Data yang dikumpulkan berupa: 1) persentase siswa yang aktif dalam proses pembelajaran; 2) persentase minat belajar kimia di kelas XI IPA melalui angket; 3) persentase siswa yang hasil belajarnya tuntas setelah dilakukan evaluasi; dan 4) nilai rata-rata kelas hasil tes.

Data yang didapat pada siklus I dianalisis sebagai refleksi dari tindakan yang telah dilakukan. Hasil analisis refleksi I digunakan sebagai acuan untuk menentukan tahapan siklus II, begitu juga siklus III merupakan refleksi siklus II

\section{HASIL DAN PEMBAHASAN}

Berdasarkan hasil pengamatan pada siklus I, penulis menemukan beberapa temuan, yaitu pembentukan kelompok berjalan baik, namun masih ada beberapa siswa yang memilih pasangan dan belum seluruh siswa yang terlibat aktif dalam diskusi kelompok. Ada juga beberapa siswa masih merasa kesulitan dalam menerangkan materi pelajaran pada teman atau pasangannya (anggota kelompok Jigsaw). Waktu yang tersedia masih kurang, karena rata rata siswa merasa kekurangan waktu untuk memahami materi. Pelaksanaan PBM sudah sesuai dengan skenario rencana pembelajaran walaupun ditemukan beberapa kendala. Peran guru sebagai motivator dan fasilitator belum begitu optimal dalam memfasilitasi dan memotivasi siswa.

Hasil analisis yang dilakukan setelah PBM pada siklus I dapat dituliskan sebagai berikut, nilai rata-rata kelas belum banyak mengalami kanaikan dibandingkan dengan kondisi awal (sebelum melaksanakan model Jigsaw) yaitu 66,6 sebelum menggunakan Jigsaw dan 73,4 setelah menggunakan model Jigsaw. Persentase siswa yang tuntas dalam belajar juga belum memperlihatkan kenaikan yang cukup masih hampir sama dengan kondisi awal yaitu $60 \%$.

Hasil analisis lembar observasi pada siklus ini sekitar $40 \%$ siswa belum aktif dalam diskusi kelompok, dan sebagian dari mereka terlihat kaku dalam menerangkan materi pada teman kelompok Jigsaw. Berdasarkan data yang diperoleh pada siklus I dan setelah dianalisis, dapat disimpulkan bahwa aktivitas belajar siswa mengalami peningkatan namun masih ada siswa yang belum aktif. Waktu yang tersedia kurang dan peran guru belum optimal sebagai motivator dan fasilitator. Perubahan hasil belajar belum signifikan.

Dari hasil analisis pada siklus I, penulis jadikan sebagai bahan pertimbangan untuk memperbaiki tindakan yang akan dilakukan pada siklus II, terutama kendala-kendala yang 
ditemui dari hasil pengamatan terhadap aktikvitas pembelajaran dan hasil analisis tes proses dan lembar observasi, maka pada siklus II ini didapatkan: Umumnya siswa sudah terlibat aktif dalam diskusi kelompok relajar. Kerjasama antar kelompok Jigsaw dalam menerangkan materi pelajaran sudah baik walaupun masih ada beberapa siswa yang terkesan membacakan teks sewaktu menerangkan materi pelajaran. Tidak ada lagi keluhan dari siswa tentang kekurangan waktu, sebab pada pertemuan sebelumnya guru sudah memberikan tugas membaca untuk masing-masing kelompok sesuai dengan sub materi yang ditugaskan. Pelaksanaan PBM sudah sesuai skenario rencana pembelajaran. Peran guru sebagai motivador dan fasilitator sangat membantu aktivitas siswa di kelas dan sikap guru yang ramah dan bersahabat berpengaruh dalam menciptkan suasana belajar yang kondusif.Hasil análisis yang telah dilakukan setelah PBM pada siklus II mengalami kenaikan dari nilai rata-rata kelas, pada siklus I yaitu dari 73,4 menjadi 79,3 . Presentase siswa yang tuntas dalam belajar memperlihatkan kenaikan yang sangat signifikan dibanding dengan siklus I, yaitu dari $50 \%$ menjadi $70 \%$.

Hasil analisis lembar observasi dibandingkan dengan siklus I, pada siklus II ini terlihat aktivitas siswa lebih meningkat. Umumnya mereka sudah terlihat aktif dalam diskusi kelompok yaitu sekitar 70\%. Dalam kelompok Jigsaw sudah terjadi kerjasama yang baik, mereka lebih tenang dalam berbagi informasi tentang materi pelajaran masing masing. Pada siklus ini penulis juga melihat siswa sudah termotivasi dalam belajar.

Berdasarkan data yang di peroleh pada siklus II dan setelah dianalisis dapat disimpulkan bahwa secara umum siswa sudah terlibat aktif dalam PBM. Waktu tidak lagi menjadi kendala. Belum ada anggota kelompok Jigsaw yang menggunakan media alat peraga dalam menerangkan materi pelajaran kepada pasangannya. Persentase siswa yang tuntas dalam belajar mengalami kenaikan begitu juga dengan nilai rata-rata kelas, namun penulis merasa perolehan nilai tersebut belum maksimal.

Hasil analisis pada siklus II penulis jadikan sebagai bahan pertimbangan untuk memperbaiki tindakan yang akan dilakukan pada siklus III sehingga diperoleh hasil yang maksimal baik dari segi peemahaman konsep maupun aktivitas belajar siswa.
Hasil pengamatan terhadap aktivitas pembelajaran dan hasil análisis dari tes proses, tes hasil belajar dan lembar observasi pada siklus III ini yang diperoleh seluruh siswa terlihat aktif dalam diskusi kelompok. Adanya kerjasama yang baik antar anggota kelompok Jigsaw. Ini terlihat dari cara mereka menerangkan materi pelajaran pada pasangannya memperlihatkan banyak kemajuan yaitu mereka sudah menggunakan media- media yang relevan.

Pemanfaatan waktu untuk diskusi antar kelompok belajar Jigsaw sudah sangat efesien, sehingga waktu yang tersisa untuk menyimpulkan pelajaran dan tes lebih longgar. PBM terlaksana sesuai skenario rencana pembelajaran. Suasana kelas sangat kondusif dan hidup. Disini guru bukan lagi sebagai sentral tapi sebagai motivator dan fasilitator. Hasil analisis tes yang dilakukan setelah PBM pada siklus III adalah nilai rata-rata kelas mengalami kenaikan dibanding siklus II yaitu dari 79,3 menjadi 81,0. Persentase siswa yang tuntas dalam belajar memperlihatkan kenaikan yang sangat signifikan dibanding siklus II yaitu dari $70 \%$ menjadi $90 \%$.

Pada tahap observasi, penulis kemajuan yang luar biasa, dimana umumnya siswa sangat antusias mengikuti proses pembelajaran, ini terlihat dengan keterlibatan masing-masing individu dalam diskusi kelompok. Sewaktu menerangkan materi pelajaran pada teman kelompok Jigsaw, banyak diantara siswa yang sudah memanfaatkan media pembelajaran.

Hasil wawancara penulis dengan siswa sehubungan dengan proses pembelajaran dengan model Jigsaw dapat disimpulkan sebagai berikut: 1) pada siklus I siswa mengalami kesulitan dalam menerangkan materi pelajaran pada teman kelompoknya, karena siswa belum terbiasa melakukannya dan merasa kekurangan waktu; 2) pada siklus II mulai terbiasa dengan model pembelajaran Jigsaw walaupun masih ada beberapa siswa yang mengalami kesulitan dalam menerangkan materi pelajaran; 3) pada siklus III terlihat perubahan yang sangat berarti, dimana siswa merasa bersemangat dan antusias sekali mengikuti PBM. Siswa juga merasa tidak jenuh dalam belajar karena terlihat aktif dalam PBM.

Dalam Penelitian Tindakan Kelas ini hipotesis diuji berdasarkan temuan data di lapangan dengan hasil pada Tabel 1. 
78 | Jurnal Zarah, Vol. 7 No. 2 (2019)

Tabel 1. Data PTK yang Diperoleh

\begin{tabular}{lcc}
\hline $\begin{array}{l}\text { Hasil Analisis yang } \\
\text { diperoleh }\end{array}$ & $\begin{array}{c}\text { Rata-rata } \\
\text { kelas }\end{array}$ & $\begin{array}{c}\text { Persen } \\
\text { Ketuntasan }\end{array}$ \\
\hline $\begin{array}{l}\text { Sebelum } \\
\text { menggunakan }\end{array}$ & 66,6 & 50 \\
model & & \\
Siklus I & 73,4 & 60 \\
Siklus II & 79,3 & 70 \\
Siklus III & 81,0 & 90 \\
\hline
\end{tabular}

Adapun persentase ketuntasan digambarkan sebagai berikut:

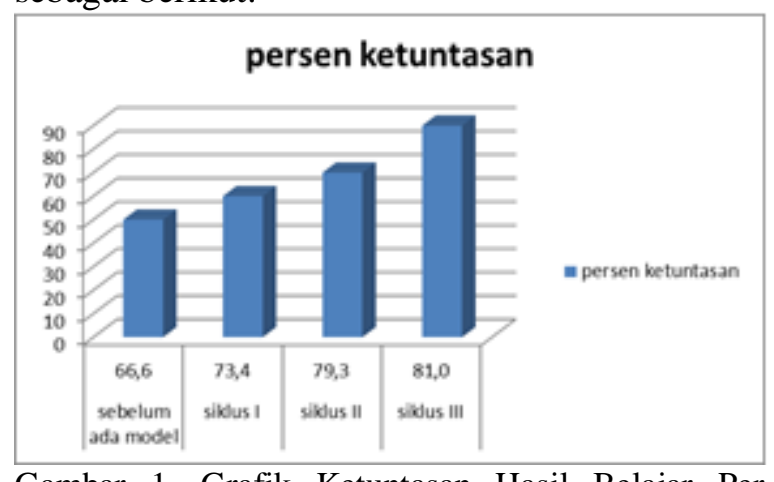

Gambar 1. Grafik Ketuntasan Hasil Belajar Per Siklus

Dari hasil analisis data dan diagram di atas ternyata hipotesis diterima yaitu penggunaan model pembelajaran Jigsaw dapat meningkatkan hasil belajar dan pemahaman konsep kimia di siswa kelas XI IPA SMA N 1 Batam. Tentu saja berbagai faktor juga berpengaruh terhadap keberhasilan penggunaan model pembelajaran Jigsaw yang didapatkan dari hasil observasi, yakni sikap guru yang ramah, bersahabat dan kemampuannya menjadi motivator dan fasilitator sangat berperan dalam menciptakan iklim belajar yang kondusif sehingga model pembelajaran ini mampu memotivasi siswa dalam mempelajari kimia dan pada akhirnya mampu meningkatkan hasil belajar dan pemahaman konsep kimia.

\section{KESIMPULAN}

Berdasarkan penelitian tindakan kelas yang telah dilakukan, didapatkan hasil bahwa pembelajaran kimia dengan model Jigsaw learning dapat meningkatkan hasil belajar dan pemahaman konsep kimia siswa di kelas XI IPA 1 SMA Negeri 1 Batam.

Adapun beberapa saran yang dapat disampaikan dalam penelitian ini yaitu 1) Guru sebagai motivator harus mampu memotivasi siswa dalam belajar; 2) Guru dituntut untuk selalu kreatif dan mau melakukan inovasiinovasi dalam pembelajaran baik dari segi strategi, metode atau model pembelajaran; 3) Guru haruslah mau mengoreksi diri dalam melakukan proses pembelajaran. Kekurangan dan kelemahan harus diakui secara sportif dan mau berusaha mengubahnya kearah yang lebih baik; 4) Guru dituntut melakukan penelitianpenelitian sehubungan dengan proses pembelajaran, seperti penlitian tindakan kelas sehingga permasalahan-permasalahn yang ditemukan dalam PBM secara berangsur-angsur dapat dicari solusinya.

\section{DAFTAR RUJUKAN}

Sugianto. (2010). Model-model Pembelajaran Inovatif. Surakarta: Yuma Pustaka.

Zaini, H. (2008). Strategi Pembelajaran Aktif. Yogyakarta: Pustaka Insan Madani 